\title{
Preparation of Sweet Potato Chips by Combined Method in Different Thicknesses
}

\author{
Silvana N. Oliveira ${ }^{1}$, Mário E. R. M. Cavalcanti Mata ${ }^{2}$, Maria E. Duarte ${ }^{2}$, Raimundo Bernadino Filho ${ }^{1}$, \\ Andréia G. C. Rosal ${ }^{1}$, Marteson C. S. Camelo ${ }^{1}$, Cícera G. C. Lisboa ${ }^{3}$, Alisson B. B. Sousa ${ }^{4}$ \\ \& Vanessa M. S. Santiago ${ }^{2}$ \\ ${ }^{1}$ Federal Rural University of Pernambuco, Garanhuns Academic Unit, Garanhuns, PE, Brazil \\ ${ }^{2}$ Federal University of Campina Grande, Science and Technology Center, Campina Grande, PB, Brazil \\ ${ }^{3}$ Institute of Technology Education, Juazeiro do Norte, CE, Brazil \\ ${ }^{4}$ Federal Institute of Education, Science and Technology of Pernambuco, Afogados da Ingazeira, PE, Brazil \\ Correspondence: Silvana N. Oliveira, Federal Rural University of Pernambuco, Garanhuns Academic Unit, \\ Garanhuns, PE, Brazil. Tel: 55-879-8316-870. E-mail: silvana_nazareth@yahoo.com.br
}

Received: January 16, 2019

Accepted: February 19, 2019

Online Published: April 15, 2019

doi:10.5539/jas.v11n5p296

URL: https://doi.org/10.5539/jas.v11n5p296

\begin{abstract}
The objective of this research was to prepare sweet potato chips (Ipomoea batatas L.) in three different thicknesses $(0.75,1.25$ and $1.75 \mathrm{~mm})$ using a combined oven drying and frying process at three different temperatures $\left(60,70\right.$ and $80{ }^{\circ} \mathrm{C}$ ) and to evaluate its centesimal composition, water content and texture (rupture resistance). The water and ash contents increased as the thickness increased and the opposite effect was observed for the lipids that reduced with increasing thickness. For the absorption of fat and calories, the chips presented varied values that can be attributed to the fact that the chips did not undergo the process of exhaustion after the frying. The highest values of rupture resistance (RR) were observed for the chips of $1.75 \mathrm{~mm}$ and the absorption of fat and water content interfered directly in this resistance. The sweet potato chips with lower caloric value were those that had drying at $60{ }^{\circ} \mathrm{C}$ in the thicknesses of 0.75 and $1.75 \mathrm{~mm}$, however the best sample were chips with $0.75 \mathrm{~mm}$ thickness by the drying treatment at $60{ }^{\circ} \mathrm{C}$ combined with frying, taking into account the values of water content, calories and fracture.
\end{abstract}

Keywords: sweet potato, combined method, frying

\section{Introduction}

Sweet potato (Ipomoea batatas L.) is a tropical and subtropical plant which is also cultivated in temperate regions. Considered as one of the most popular tuberous crops in Brazil, much appreciated as food, being consumed in the form of baked or cooked and industrialized as sweet, and can be found with external colors, yellow, white and purple (Silva, Lopes, \& Magalhães, 2010). It is a plant of great socioeconomic importance, participating in the supply of calories, vitamins and minerals in human food. The roots present carbohydrate content between 13.4 to $29.2 \%$ and reducing sugars of 4.8 to $7.8 \%$. They are also excellent sources of carotenoids, potassium, iron and calcium (Embrapa, 2010).

Due to the excellent characteristics of sweet potato production, the perishability of this tuber and the lack of alternatives for industrialization have been pointed out as causes that restrict the expansion of this crop, causing a loss of capital. According to Grizotto (2010) the composition of sweet potatoes and their potential agricultural potential mean that this tuber can be used as raw material for various foods such as chips products, which have been occupying a growing space in the Brazilian market. However, one of the most important parameters in the quality of chips products is the amount of oil incorporated during the process, mainly because it is incompatible with the world trend of consumption of healthy products and low calorie and fat (Bouchon \& Pyle, 2006).

One of the industrial processes that has proven efficient in obtaining food products is drying, being feasible in the processing of foods with high amounts of starch, such as tubers. Drying makes it possible to ensure the quality and stability of the products, considering that the decrease in the amount of water in the material reduces the biological activity and the chemical and physical changes that occur during storage (Resende, Corrêa, Goneli, Botelho, \& Rodrigues, 2008). 
In this scenario, the objective of this research was to prepare sweet potato chips in three different thicknesses using a combined oven drying and frying process, and to evaluate their centesimal compositions, water contents and textures.

\section{Material and Methods}

\subsection{Raw Material}

Sweet potato (Ipomoea batatas L.) of the purple peel and beige pulp variety acquired from a single producer in commercial unit of organic products in the city of Campina Grande, Paraíba/Brazil, was used for the accomplishment of this research. The tubers were selected for their physical integrity and sanity.

\subsection{Obtaining the Sweet Potato Chips}

The flowchart in Figure 1 shows the sequence of operations for obtaining sweet potato chips (Figure 2) in different thicknesses.

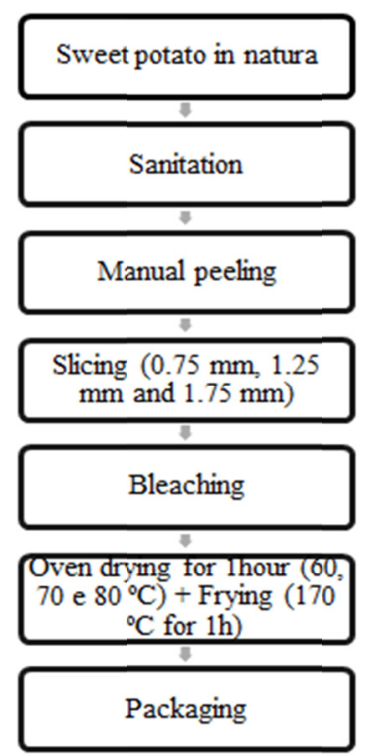

Figure 1. Flowchart of obtaining sweet potato chips 


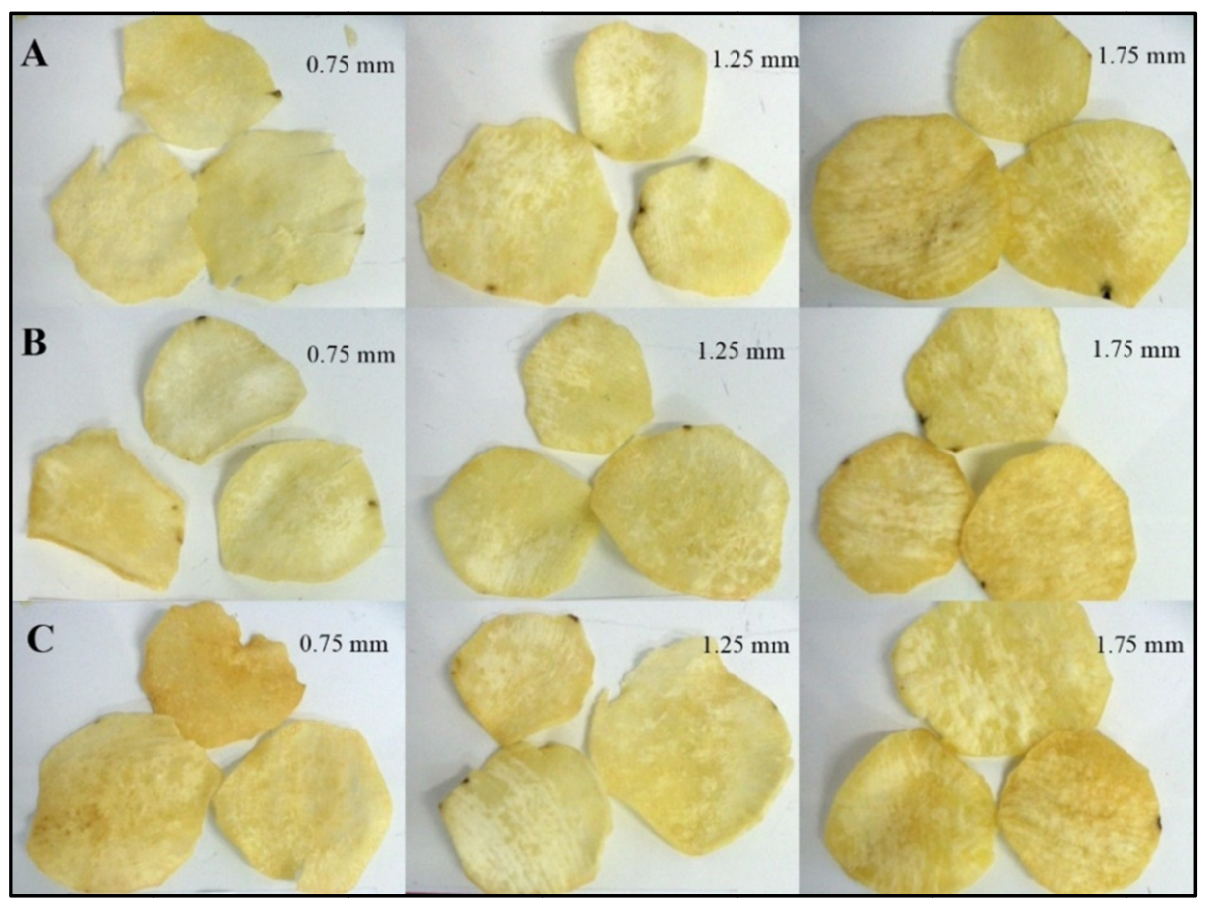

Figure 2. Sweet potato chips in different thicknesses

Note. Chips subjected to drying temperature of: A: $60^{\circ} \mathrm{C} ; \mathrm{B}: 70{ }^{\circ} \mathrm{C}$ and $\mathrm{C}: 80^{\circ} \mathrm{C}$.

The tubers were washed in running drinking water to remove excess dirt, then washed with neutral detergent and immersed in hypochlorite solution for $15 \mathrm{~min}$ to reduce microbial flora. The debarking was carried out manually. After removal of the bark, the tubers were sliced in three different thicknesses $(0.75 \mathrm{~mm}, 1.25 \mathrm{~mm}, 1.75 \mathrm{~mm})$, and their thicknesses were measured using a digital caliper. Slices of fresh potato in natura in portions of $100 \mathrm{~g}$ were immersed in $6 \mathrm{~L}$ of boiling water with $72 \mathrm{~g}$ of sodium chloride $(\mathrm{NaCl})$ added. To perform bleaching, the $0.75 \mathrm{~mm}$ slices were immersed for $30 \mathrm{~s}$; those of $1.25 \mathrm{~mm}$ for $40 \mathrm{~s}$ and those of $1.75 \mathrm{~mm}$ for $60 \mathrm{~s}$, respectively. After the bleaching the chips were submitted to a drying process in an oven with circulation of air for $1 \mathrm{~h}$ at temperatures of 60,70 and $80{ }^{\circ} \mathrm{C}$ and then submitted to frying in electric fryer at $170{ }^{\circ} \mathrm{C}$ for $1 \mathrm{~min}$. The chips obtained (Figure 2) were separated into portions of approximately $150 \mathrm{~g}$ and packaged in metallized flexible packaging, sealed under partial vacuum.

\subsection{Centesimal Composition and Water Activity}

For determination of the ashes, the samples were in a muffle oven at $550{ }^{\circ} \mathrm{C}$ until constant weight; for the determination of lipids the extraction with hexane in Soxhlet apparatus was used and for the determination of the proteins the Kjeldahl digestion process was used. All methodologies are described in the Analytical Standards of the Adolfo Lutz Institute (IAL, 2008). The values of carbohydrates were determined by difference and for calorie determination the conversion factors, $\mathrm{kcal}=(9 \times$ lipids $)+(4 \times$ proteins $)+(4 \times$ total carbohydrates $)$ were calculated according to the calculation of the energy value of the ANVISA Resolution RDC $n^{\circ} 360 / 03$ (Brazil, 2003). The water content of the samples was determined by the gravimetric method, as described by Adolfo Lutz Institute (2008).

The determination of the water activity was performed with the aid of the Aqualab CX-2T equipment, Decagon at $25^{\circ} \mathrm{C}$, presenting an error of +0.003 in the final value.

\subsection{Texture}

The texture analysis based on the chip fracturability was determined through the TPA (Texture Profile Analysis) method performed in a Universal texturometer. Destructive tests were performed on the maximum strength of the sample at rupture. The measurements were conducted at room temperature $\left(25^{\circ} \mathrm{C}\right)$. The obtained values refer to the maximum force applied on the sample, given in Newton $(\mathrm{N})$, with rupture resistance (RR) calculated by the equation described below, 


$$
\mathrm{RR}=\frac{\mathrm{F}_{\mathrm{m}}}{\mathrm{A}}
$$

where, $\mathrm{RR}=$ corresponds to rupture resistance $(\mathrm{Pa}) ; \mathrm{Fm}=$ maximum force at the moment of chip rupture $(\mathrm{N})$; $\mathrm{A}$ $=$ cross-sectional area $\left(\mathrm{m}^{2}\right)$.

\subsection{Statistical Analysis}

The results obtained in the centesimal composition were analyzed statistically to identify the best treatment for obtaining sweet potato chips. The data were interpreted through the analysis of variance and the averages of the treatments compared by applying the Tukey test. The program used was the Assistat 7.5 beta. (Silva \& Azevedo, 2016)

\section{Results and Discussion}

\subsection{Centesimal Composition and Water Activity}

Analyzing Table 1, it can be observed that the values of water content and ash content of the chips increased as the thickness increased, a contrary effect is observed for the lipids which reduced with increasing thickness. There was a statistically significant difference for the parameters of water content, water and protein activity with increasing treatment temperature.

According to the Brazilian Table of Food Composition (2006), the water content of potato chips, industrialized type chips is $2.37 \%$. Table 1 shows that the lowest water content is $3.25 \%$, observed in the sweet potato chips at the lowest thickness and pre-dehydrated at $80{ }^{\circ} \mathrm{C}$. Also in Table 1 it is observed that for the water content of sweet potato chips of the same thickness dehydrated at different temperatures, there were significant differences in level of $5 \%$ of probability between the chips, being different water contents. Rogério, Leonel and Oliveira, (2005) (who studied the characterization of chips of tropical tuberoses (cassava, Arracacia xanthorrhiza, sweet potato, taro and yam), observed that in the processing of sweet potato, water loss during frying and water content of sweet potato chips reached 3.09\%, an approximate value for the present study.

In relation to proteins, a variation of 1.26 to $1.85 \%$ is observed, Carvalho, Seccadio and Ferreira (2010) studying cassava chips obtained values of 0.97 to $1.06 \%$, Oliveira (2009) analyzing different brands of fried potatoes chips, obtained values of proteins varying from 6.35 to $11.60 \%$. Analyzing the values (Table 1), there were significant differences at a 5\% probability level for all chips except for chips of 0.75 and $1.75 \mathrm{~mm}$ at $70{ }^{\circ} \mathrm{C}$ and $0.75 \mathrm{~mm}$ at $80^{\circ} \mathrm{C}$.

Table 1. Mean values of the centesimal composition and water activity of sweet potato chips

\begin{tabular}{|c|c|c|c|c|c|c|c|c|}
\hline \multirow[b]{2}{*}{ Drying temperatures } & \multirow{2}{*}{$\begin{array}{l}\text { Thickness } \\
(\mathrm{mm})\end{array}$} & \multicolumn{7}{|c|}{ Parameters } \\
\hline & & $\begin{array}{l}\text { Water content } \\
\text { (\%b.u.) }\end{array}$ & $\begin{array}{l}\text { Carbohydrates } \\
(\mathrm{g} / 100 \mathrm{~g})\end{array}$ & $\begin{array}{l}\text { Proteins } \\
(\mathrm{g} / 100 \mathrm{~g})\end{array}$ & $\begin{array}{l}\text { Lipids } \\
(\mathrm{g} / 100 \mathrm{~g})\end{array}$ & $\begin{array}{l}\text { Ashes } \\
(\mathrm{g} / 100 \mathrm{~g})\end{array}$ & $\begin{array}{l}\text { Calories } \\
(\mathrm{kcal} / 100 \mathrm{~g})\end{array}$ & $\mathrm{Aw}\left(25^{\circ} \mathrm{C}\right)$ \\
\hline \multirow{3}{*}{$60^{\circ} \mathrm{C}$} & 0.75 & $8.253^{\mathrm{b}}$ & $80.006^{\mathrm{d}}$ & $2.493^{b}$ & $8.493^{a}$ & $0.710^{\mathrm{g}}$ & $320.026^{\mathrm{d}}$ & $0.494^{\mathrm{d}}$ \\
\hline & 1.25 & $8.570^{\mathrm{b}}$ & $82.850^{\mathrm{c}}$ & $2.856^{\mathrm{a}}$ & $6.630^{c}$ & $0.833^{\mathrm{g}}$ & $402.496^{b}$ & $0.509^{c}$ \\
\hline & 1.75 & $17.760^{\mathrm{a}}$ & $77.506 \mathrm{e}$ & $2.000^{\mathrm{d}}$ & $2.580^{\mathrm{g}}$ & $1.493^{\mathrm{d}}$ & $310.036^{\mathrm{e}}$ & $0.667^{\mathrm{a}}$ \\
\hline \multirow{3}{*}{$70{ }^{\circ} \mathrm{C}$} & 0.75 & $6.030^{\mathrm{d}^{-}}$ & $84.113^{\mathrm{abc}}$ & $1.820^{\mathrm{e}}$ & $8.263^{\mathrm{a}}$ & $1.310^{\mathrm{e}}$ & $402.353^{\mathrm{b}}$ & $0.538^{\mathrm{b}}$ \\
\hline & 1.25 & $5.923^{\mathrm{de}}$ & $83.733^{\mathrm{bc}}$ & $1.683^{\mathrm{f}}$ & $6.513^{\mathrm{c}}$ & $1.780^{\mathrm{bc}}$ & $416.036^{\mathrm{a}}$ & $0.532^{\mathrm{b}}$ \\
\hline & 1.75 & $7.210^{c}$ & $85.850^{\mathrm{ab}}$ & $1.803^{\mathrm{e}}$ & $3.440^{\mathrm{f}}$ & $1.813^{\mathrm{b}}$ & $416.106^{\mathrm{a}}$ & $0.542^{b}$ \\
\hline \multirow{3}{*}{$80^{\circ} \mathrm{C}$} & 0.75 & $3.253^{\mathrm{f}}$ & $84.613^{\text {abc }}$ & $1.803^{\mathrm{e}}$ & $7.826^{\mathrm{b}}$ & $1.140^{\mathrm{f}}$ & $398.970^{\mathrm{b}}$ & $0.509^{\mathrm{c}}$ \\
\hline & 1.25 & $6.186^{d}$ & $86.186^{\mathrm{a}}$ & $1.263^{\mathrm{g}}$ & $5.463^{\mathrm{d}}$ & $1.666^{\mathrm{c}}$ & $398.970^{\mathrm{b}}$ & $0.489^{\mathrm{d}}$ \\
\hline & 1.75 & $6.186^{d}$ & $83.556^{\mathrm{c}}$ & $2.156^{\mathrm{c}}$ & $4.866^{\mathrm{e}}$ & $2.430^{\mathrm{a}}$ & $386.654^{c}$ & $0.493^{\mathrm{d}}$ \\
\hline DMS & & 0.45295 & 2.29145 & 0.09072 & 0.41201 & 0.12711 & 9.36296 & 0.0102 \\
\hline CV $(\%)$ & & 2.08203 & 0.96225 & 1.5947 & 2.39452 & 3.03187 & 0.85684 & 0.67453 \\
\hline
\end{tabular}

Note. Means followed by the same letters in the column do not differ from each other by the Tukey test at $5 \%$ probability. DMS = significant difference. $\mathrm{CV} \%=$ coefficient of variation in $\%$.

Rogério and Leonel (2004) studied sweet potato chips in the thicknesses of 1.5 and $2.0 \mathrm{~mm}$ under different pre-cooking conditions obtained values for lipids of 15.37 to $31.80 \%$ and observed that the pre-cooking did not interfere with the absorption of oil by the chips. According to the lipid contents of Table 1, it can be said that the drying pre-treatment is efficient with respect to the reduction of oil absorption for sweet potato chips. For the 
absorption of fat and calories, the chips presented irregular behavior that can be attributed to the fact that the chips were not subjected to the exhaustion process after frying.

According to Table 1, total carbohydrate levels presented values higher than those found by Carvalho, Seccadio and Ferreira (2010) and Oliveira (2009), which obtained values between 37.40 and $63.51 \%$ for different brands of potatoes French fries.

\subsection{Texture Analysis of Obtained Sweet Potato Chips}

Analyzing Figure 3, it can be observed that the chips at $1.75 \mathrm{~mm}$ thickness obtained the highest values of rupture resistance ranging from 2976 to $5200 \mathrm{~Pa}$ for the temperatures of 70 and $60{ }^{\circ} \mathrm{C}$ respectively.

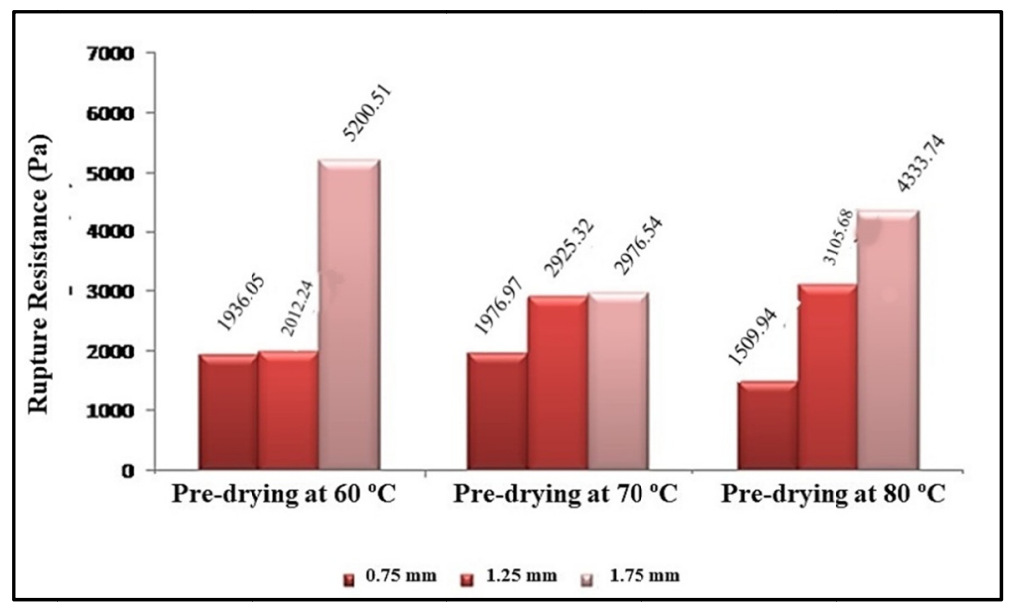

Figure 3. Mean values of rupture resistance (RR) of sweet potato chips

Vitrac, Trystam, and Raoult-Wack (2000) argue that texture and fat absorption in chips-like products may be related to water loss in frying, with products with higher fat content and water content tending to wither.

Comparing the values obtained for rupture resistance of the sweet potato chips in Figure 3 with the amount of lipids of the chips in Table 1, it is observed that the ratio of lipid content andrupture resistance was inversely proportional, since the $1.75 \mathrm{~mm}$ sweet potato chips have lower values of lipid content and higher rupture resistance (RR), but when the water content of the same chips $(1.75 \mathrm{~mm})$ is analyzed, the proof is verified that the water content directly interfered with the texture and rupturing, since it is observed in Figure 3 that the highest rupture strengths were observed in the $1.75 \mathrm{~mm}$ sweet potato chips, they presented the highest water contents when compared with the others.

\section{Conclusions}

The sweet potato chips with lower caloric value were those that had drying at $60{ }^{\circ} \mathrm{C}$ in the thicknesses of 0.75 and $1.75 \mathrm{~mm}$, however taking into account the values of water content and rupturability correlating them with the crispness of the "snacks" type products can be said that the best sample was obtained in the sample with 0.75 $\mathrm{mm}$ thickness by the treatment of drying at $60{ }^{\circ} \mathrm{C}$ combined with the frying, considering that this sample had lower water activity and average rupture of $1.94 \mathrm{~Pa}$, assigning characteristic texture to the product in question, without excess of hardness. This research can be an alternative for the food industry in the elaboration of a product with good sensory and healthier characteristics.

\section{References}

Bouchon, P., \& Pyle, D. L. (2006). Study in goil absorption in restructured potato chips. Journal of Food Science, 69(3), 115-122. https://doi.org/10.1111/j.1365-2621.2004.tb13363.x

Brazil. (2003). Resolução RDC $n^{\circ} 360$, de 23 Dezembro 2003: Regulamento técnico sobre rotulagem nutricional de alimentos embalados (Seção 1, pp. 33-34). Diário Oficial [da] República Federativa do Brasil, Brasília. Retrieved from http://www.agricultura.gov.br/sislegis

Carvalho, A. V., Seccadio, L. L., \& Ferreira, T. F. (2010). Obtenção e avaliação físico-química e sensorial de "chips" de mandioca submetidos a pré-tratamentos. Revista de Ciências Agrárias, 53(2), 182-187. https://doi.org/10.4322/rca.2011.026 
Embrapa (Empresa Estadual de Pesquisa Agropecuária da Paraíba). (2010). Cultura da batata doce (Ipomoea batatas (L) Lam.). Embrapa, Brazil. Retrieved from http://www.embrapa.org.br/publicac/batata_doce.html

Grizotto, R. K. (2006). Processamento e rendimento industrial da batata chips e palha, ITAL. Campinas. SP. Retrieved from http://www.abbabatatabrasileira.com.br/minas2005/19\%20-20Processamento $\% 20 \mathrm{da} \% 20 \mathrm{~b}$ atata $\% 20$ chips $\% 20 \mathrm{e} \% 20$ palha $\% 2001$.pdf

IAL (Instituto Adolfo Lutz). (2008). Métodos químicos e físicos para análise de alimentos (4th ed.). Normas Analíticas do Instituto Adolfo Lutz. São Paulo.

Oliveira, M. C. (2009). Composição nutricional e perfil de ácidos graxos de batatas chips e snacks extrusados (Dissertação (Mestrado em Engenharia e Ciências de Alimentos), Instituto de Biociências, Letras e Ciências Exatas, Universidade São José do Rio Preto, SP).

Resende, O., Corrêa, P. C., Goneli, A. L. D., Botelho, F. M., \& Rodrigues, S. (2008). Modelagem matemática do processo de secagem de duas variedades de feijão (Phaseolus vulgaris L.). Revista Brasileira de Produtos Agroindustriais, 10(1), 17-26. https://doi.org/10.15871/1517-8595/rbpa.v10n1p17-26

Rogerio, W. F., \& Leonel, M. (2004). Efeitos da espessura das fatias e pré-cozimento na qualidade de salgadinhos fritos (chips) de tuberosas tropicais. Revista Alimentação e Nutrição, 5(2), 131-137.

Rogério, W. F., Leonel, M., \& Oliveira, M. A. (2005). Produção e caracterização de salgadinhos fritos de tuberosas. Revista Raízes e Amidos Tropicais, 1(1), 76-85.

Silva, F. de A. S., \& Azevedo, C. A. V. de. (2016). The Assistat Software Version 7.7 and its use in the analysis of experimental data. Afr. J. Agric. Res., 11(39), 3733-3740. https://doi.org/10.5897/AJAR2016.11522

Silva, J. B. C., Lopes, C. A., \& Magalhães, J. S. (2010). Produção de batata doce. Brasília: Embrapa Hortaliças. Retrieved from http:/www.cnph.embrapa.br/sistprod/batatadoce/origem.htm

Tabela Brasileira de Composição de Alimentos. (2006). Núcleo de Estudos e Pesquisas em Alimentação-NEPA. Universidade Estadual de Campinas, Campinas-SP, Gráfica e Editora Flamboyant Ltda.

Vitrac, O., Trystam, G., \& Raoult-Wack, A. L. (2000). Deep-fat frying of food: Heat and mass transfer, transformations and reactions inside the frying material. European Journal of Lipid Technology, 102, 529-538. https://doi.org/10.1002/1438-9312(200009)102:8/9<529::AID-EJLT529>3.0.CO;2-F

\section{Copyrights}

Copyright for this article is retained by the author(s), with first publication rights granted to the journal.

This is an open-access article distributed under the terms and conditions of the Creative Commons Attribution license (http://creativecommons.org/licenses/by/4.0/). 